\title{
The map of vegetation complexes of the Seili island and its surroundings (SW Finland)
}

\author{
Maria Wojterska*, Stanisław Balcerkiewicz \& Andrzej Brzeg
}

Department of Plant Ecology and Environmental Protection, Faculty of Biology, Adam Mickiewicz University in Poznań, Umultowska 89, 61-614 Poznań, Poland

* corresponding author (e-mail: mwzerios@amu.edu.pl)

\begin{abstract}
The paper gives the results of studies on vegetation complexes of 12 islands and several skerries, situated within the inner part of SW Finnish archipelago. There were differentiated 14 types of complexes, comprising all types of communities (of vascular plants, mosses and lichens). All complexes are characterised by a repetitive combination of communities. Their distribution, showing distinct regularities in relation to geology, geomorphology and situation on an island, is depicted in the map.
\end{abstract}

Key words: vegetation landscape, sigmassociation method, inner archipelago, Turku

\section{Introduction}

The landscape of the archipelago was shaped by icesheets, which on bigger islands resulted in a sequence of polished rocky elevations separated by depressions filled with marine deposits. This regular mosaic of landforms influenced also the pattern of vegetation, transformed further by human activities.

The geobotanical studies on the landscape level with the implementation of the concept of sigmassociations (e.g. Tüxen 1973, 1978, 1979; Rivas-Martinez 1976; Balcerkiewicz et al. 1996) have not been conducted in Finland. This concept was implemented in geobotanical cartography in several European countries, e.g.: in Germany (Tüxen 1977; Schwabe 1987), Norway (Thannheiser 1982), Poland (Balcerkiewicz \& Wojterska 1978; Medwecka-Kornaś 1983; Ratyńska 2003; Wojterska 2003), Switzerland (Theurillat 1992).

The aim of our studies was to show the structure of vegetation landscape taking into account possibly broad scope of communities and to present it in a form of a map.

\section{Study area}

Geobotanical studies covered a fragment of archipelago around island Seili $\left(60^{\circ} 14^{\prime} \mathrm{N}\right.$ of latitude and $21^{\circ} 58^{\prime}$ E longitude) and 12 smaller adjacent islands: Päiväluoto, Jäämäluoto, Högholmen, Lammasluoto, Kolkan, Katavaluoto, Ålderman, Björkholmen, Kalvgrundet, Saunasaari, Siikakari, Matinkari, as well as 7 singular skerries or their groups (Fig. 1), all located in a $3.4 \times 3.4 \mathrm{~km}$ square $\left(11.56 \mathrm{~km}^{2}\right)$. In the Finnish biogeographic division (after Hämet-Ahti et al. 1998) the study area belongs to Regio aboënsis. From the phytogeographic point of view, it is situated at the northern boundary of the boreo-nemoral (after Sjörs 1965) or hemiboeral zone (after Ahti et al. 1968).

The climate of the islands is humid with medium precipitation $600 \mathrm{~mm} / \mathrm{yr}$ and temperature $5^{\circ} \mathrm{C}$; the precipitation is lower and temperature higher compared to the mainland ( $612 \mathrm{~mm}$ and $4.5^{\circ} \mathrm{C}$ respectively) and there are more sunny days in the year compared to Turku (Petäjä \& Juusti 1979; Tuhkanen 1980). Within geological substrates predominate the Precambrian cristalline granite and gneiss rocks with a small share of tills, coarse sand and gravel of different origin. Valleys are filled with marine deposits (Maaperäkartta 1997). Maximum elevation is $55 \mathrm{~m}$ a.s.l. on the island Högholmen, and all culminations are formed by glacially polished rock outcrops. The total land upheaval is $5 \mathrm{~mm}$ per year (Petäjä \& Juusti 1979; Ericson \& Wallentinius 1979). The size of islands varies from 0.1 to 163 ha. 


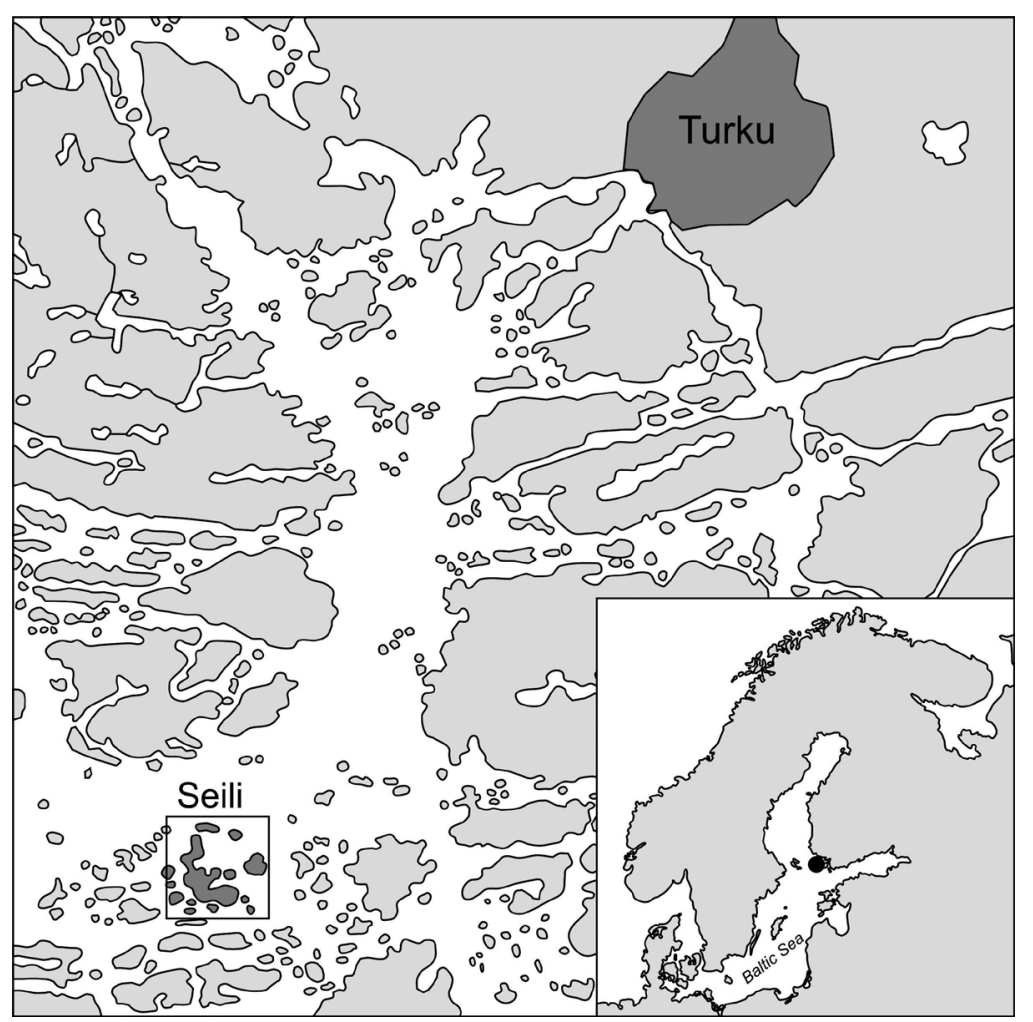

Fig. 1. Map of the study area

\section{Material and methods}

Geobotanical landscape analyses on Seili island were conducted according to the concept of sigmassociation (Tüxen 1973, 1978, 1979) in the years 1979-1986. Described were complexes connected with given landforms with uniform geological substrate and with a form of land use. The criterion of uniformity of environmental conditions was not taken into account, and as a result in the list of communities may co-occur e.g. these of dry rocks and of small (several square meters) depressions filled with peat and situated on the highest tops. For each type of complex were noted all communities (dominant of vascular plants and accompanying communities of cryptogamous plants and lichens, as well as synusial or dependent communities, e.g. on rock outcrops or tree stems). In each complex the cover of communities was estimated according to Braun-Blanquet scale, whereas for description of the way of their occurrence some graphic symbols were adopted after Tüxen (1973): O (circle) - big surfaces, / (slash) - narrow, linear forms, . (dot) - small, singular or scattered patches. In the lists have been used following abbreviations: comm. - community without ascribed rank, deg. - degenerated forms of phytocoenoses, fragm. - fragmentarily developed phytocoenoses.

Each type of complex was characterised by a symphytosociological relevé in the field. Out of 75 archival relevés (Balcerkiewicz \& Wojterska 1998) there have been chosen 17 , to illustrate the composition of complexes. The delimitation of units presented on the map was made contemporarily on the basis of an earlier map of real vegetation (Wojterski \& Wojterska 1993; Wojterski et al. 1998). The syntaxonomy of plant communities follows Klement (1955), Wirth (1972), von Hübschman (1975), Dierssen and Dierssen (1996), Wojterska (1998), Balcerkiewicz and Brzeg (2001), Kasprowicz and Wojterska (2004), and contemporary nomenclature of communities occurring also in Poland follows Ratyńska et al. (2010). The names of authors were attached to all validly described syntaxa, when they were mentioned for the first time in the cited symphytosociological relevés. Some exceptions were made for invalid names, when they concerned syntaxa in a rank of association.

\section{Results}

In the study area there were differentiated 14 types of vegetation complexes (Fig. 2). Some of them covered vast areas, whereas the others were of limited surface.

I. Complex of oligotrophic pine and spruce forests was stated on several bigger and higher islands, and was connected with glacially polished, relatively dry rocks. On their tops, South exposed slopes and flat parts dominated phytocoenoses of Cladino-Pinetum in 


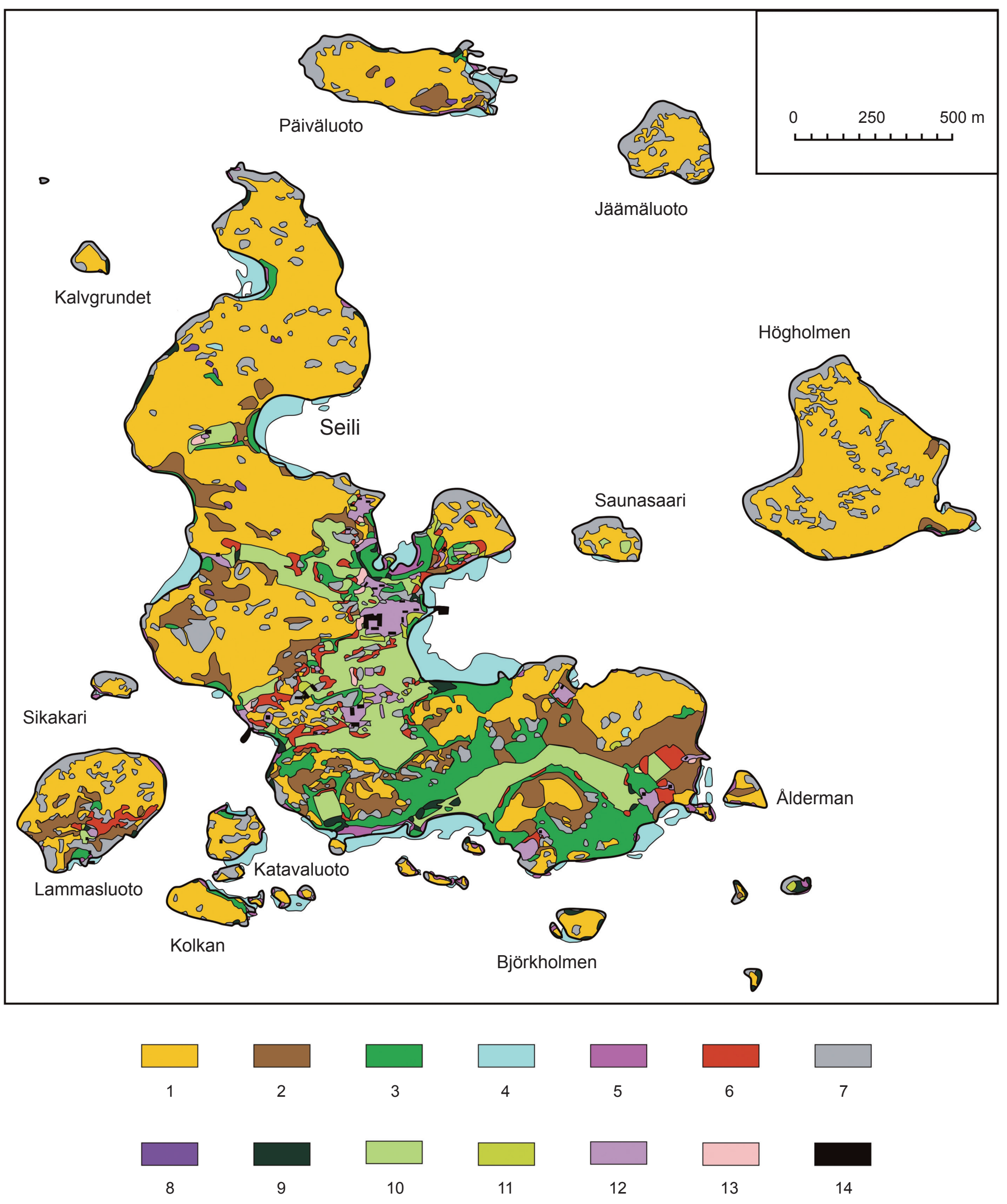

Fig. 2. Generalised map of vegetation complexes of Seili and adjacent islands

Explanations: complex of: 1 - oligotrophic pine and spruce forests, 2 - oligo-mesotrophic mixed coniferous forests, 3 - meso-eutrophic deciduous forests and thickets, 4 - reeds, 5 - coastal halophytes, 6 - xerothermophilous swards, forest edges and thickets, 7 - epilithic communities, 8 - peat bogs and mires, 9 coastal tall herbs and grasslands, 10 - meadows, pastures and heathlands, 11 - nitrophilous forest edge communities, 12 - ruderal communities, 13 - segetal communities, and 14 - buildings and piers 
a mosaic with Vaccinio vitis-idaeae-Pinetum, whereas on the slopes slightly inclined towards the North more common was Linnaeo-Piceetum. As admixture occurred xerophilous epilithic communities, and in small depressions, Scheuchzerio-Caricetea fuscae communities or tussocks of Sphagnum capillifolium. The complex covered the largest part of the study area and occurred most frequently in the mosaic with complexes of epilithic communities and of mixed coniferous forests. Two symphytosociological relevés cited below can be an example of composition of this type of vegetation complex:

(1) Field No 35: Cladino-Pinetum Juraszek 1928 nom. invers. 4O, Vaccinio vitis-idaeae-Pinetum (Caj. 1921) K.-Lund 1967 2O, Linnaeo-Piceetum abietis (Caj. 1921) K.-Lund 1962 ex Dierssen $1996+$ +., Juniperus communis thickets 1., Scheuchzerio-Caricetea fuscae (Nordh. 1936) R. Tx. 1937 comm. +., Woodsio-Asplenietum septentrionalis $\mathrm{R}$. Tx. 1937 r., Hypogymnietalia physodo-tubulosae Barkm. 1958 comm. 2., Parmeliopsidetum ambiguae Hilitzer 1925 1., Parmelietalia saxatilis Wirth 1972 comm. +., Cladina rangiferina-C.mitis comm. +., Andreaeion rupestris Hadač et Klika comm. 1944 +., Rhacomitrion lanuginosi v. Krusenstjerna 1945 comm. r., Parmelia incurva-Parmelia sorediosa comm. r.; tree stumps testify to some anthropogenic influence;

(2) Field No 16: Vaccinio vitis-idaeae-Pinetum 3O, LinnaeoPiceetum abietis 30, Linnaeo-Piceetum abietis deg. Pinus sylvestris 1O, Cladino-Pinetum 1O, Dicranum-Cladonia comm. +., Hypogymnietalia physodo-tubulosae fragm. r.; presence of pine plantation on small area indicates anthropogenic transformation of tree stand.

II. Complex of oligo-mesotrophic mixed coniferous forests occurred mainly in the southern and central part of Seili, and was scattered in a form of small patches on some other islands. Main communities were Melico nutantis-Piceetum abietis and/or Melico-Pinetum. It occurred in lower parts of slopes or in depressions filled with coarse deposits, usually in the transitional zone between oligotrophic coniferous forests and deciduous forests. Its composition is illustrated by a following relevé:

(3) Field No 29: Melico nutantis-Piceetum abietis (Caj. 21) K.-Lund 1962 4O, Melico nutantis-Piceetum abietis deg. Picea abies 1O, Melico-Pinetum Marker $69 \mathrm{em}$. Kaspr. et M. Wojt. 1999 2O, Hypogymnietalia physodo-tubulosae fragm. 1., Calamagrostietum epigeji Juraszek $1928+\mathrm{O}$, Lathyro montani-Melampyretum pratensis Pass. 1967 +/. Spruce plantation indicates some forest management activities.

III. Complex of meso-eutrophic deciduous forests and thickets occurred in the form of bigger patches mainly in the southern part of Seili. Dominant were Ulmo-Tilietum or Melico-Coryletum on mesic habitats, and Lysimachio vulgaris-Alnetum glutinosae on humid sites. The complex was partially transformed by plantations of coniferous and deciduous trees on former arable fields. Its patches were neighbouring with the complexes of oligo-mesotrophic mixed coniferous forests and meadows. The exemplary relevé is:

(4) Field No 47: Ulmo-Tilietum K.-Lund in Seibert 1969 1./, Ulmo-Tilietum deg. Pinus/Picea 3O, Melico-Coryletum Fremstad 1979 3O, Lysimachio vulgaris-Alnetum glutinosae K.-Lund 1971 1O, Ulmo-Fraxinetum Sjögren 1971 +., Ribes alpinum-Sorbus aucuparia comm. +., Alopecurus pratensis comm. with Betula sp. cult. 2O, Alopecurus pratensis comm. +O, Potentilletum anserinae Rapaics 1927 em. Pass. 1964 1/, Trifolio medii-Agrimonietum Th. Müller 1962 1/, Calamagrostietum epigeji + /, Potentillo argenteae-Viscarietum vulgaris Balcerk. et Brzeg $2001+$ +., Grimmietalia hartmanii Philippi 1956 fragm. r., Parmelietalia saxatilis comm. r..

IV. Complex of reeds was occurring in shallow, sheltered bays on Seili and Päiväluoto and between smaller islands and skerries. Besides plant communities, among them dominant Phragmitetum communis, in the majority of patches the constant element constituted dead reed stems drifted ashore.

(5) Field No 58: Phragmitetum communis (Gams 1927) Schmale 1939 4O, Lysimachio vulgaris-Alnetum glutinosae 2/, Phalaridetum arundinaceae Libb. 1931 1/, Juncetum gerardii Nordh. 1923 1/, Lysimachio vulgaris-Filipenduletum Bal.-Tul. 1978 1/.

V. Complex of coastal halophytes, with dominating different forms of Juncetum gerardii, occurred along flat, low shores, frequently in the vicinity of reeds, coastal tall herbs and grasslands, or more rarely along rows of alder trees. The exemplary relevé is:

(6) Field No 11: Juncetum gerardii 5O/, Phragmitetum communis 1O, Scirpetum maritimi Soó 1927 ex Eggler 1933 em. R. Tx. 1937 1O, Phalaridetum arundinaceae 1/, Soncho palustris-Archangelicetum litoralis R. Tx. 1937 fragm. 1/, Alnus glutinosa tree rows 1/, Lysimachio vulgarisFilipenduletum +.

VI. Complex of xerothermophilous swards, forest edges and thickets was represented by numerous small patches, which were connected with areas of former grazing, scattered in the central and southern part of Seili and on Lammasluoto. Besides listed below dominant swards, worth mentioning is strongly xerotermophilous forest edge community Lathyro sylvestris-Vincetoxicetum.

(7) Field No 18: Potentillo argenteae-Viscarietum vulgaris 3O, Galio veri-Avenuletum pubescentis Brzeg 1999 nom. inval. 3O, Parmelietalia saxatilis comm. 2., Calamagrostietum epigeji $1 \mathrm{O}$, Vaccinio vitis-idaeae-Pinetum $1 \mathrm{O}$, Lathyro montani-Melampyretum pratensis 1/, Poo irrigatae-Plantaginetum R.Tx 1970 1/, Juniperus communis thickets 1., Rosetum rubiginoso-dumalis Brzeg et Wojterska 2001 1., Ribes alpinum-Sorbus aucuparia comm. 1., Alopecurus pratensis comm. $+\mathrm{O}$, Matricario matricarioidis-Polygonetum arenastri Th. Müller in Oberd. $1971+/$. .

VII. Complex of epilithic communities occurred on highest elevations within oligotrophic coniferous forests and on high and steep coastal rocks. Dominant were lichen communities, but also typical were areas of bare rocks. 
(8) Field No 45: Umbilicarietum deustae (Hilitzer 1925) Frey 1933 3O, Andreaeion rupestris comm. 2O, Parmelietalia saxatilis comm. 20, Cladino-Pinetum 10, Cladina rangiferina-C. mitis comm. 10 , Verrucarietum maurae Klem. 1955 1/, Lasalietum pustulatae Hilitzer 1925 1., Juniperus communis thickets 1. , Dicranum-Cladonia comm. + ., Asplenio-Polypodietum Firbas $1924+$ +, Sedum acre-Allium schoenoprasum comm. +., Woodsio-Asplenietum septentrionalis r., Vaccinio vitis-idaeae-Pinetum r., ScheuchzerioCaricetea fuscae fragm. r., Oxycocco-Sphagnetea Br.-Bl. et R. Tx. 1943 fragm. r..

VIII. Complex of peat bogs and mires covered small areas and was limited to shallow depressions within oligotrophic coniferous forests. It comprised forests on peaty soil and usually fragmentarily developed nonforest communities.

(9) Field No 17a: Sphagno girgensohnii-Piceetum Polakowski 1962 2O, Sphagno-Alnetum Allorge ex Lemée 1937 2O, Scheuchzerio-Caricetea fuscae comm. 3O, Linnaeo-Piceetum abietis 2/, Polytrichum commune comm. 2., Glyceria fluitans comm. + ..

IX. Complex of coastal tall-herbs and grasslands occurred most often on skerries or on the flat coast of larger islands, exposed to the East, with gravel and stones sprayed with sea water, in places where some organic debris had been accumulated. Its patches bordered with halophytic vegetation. Composition of this complex is differentiated, as in two exemplary relevés:

(10) Field No 62: Leymus arenarius-Sonchus arvensis comm. 3/, Phalaridetum arundinaceae 2/, Alnus glutinosa tree rows 1/, Verrucarietum maurae 1/, Juncetum gerardii +/, stones without vegetation 30 ;

(11) Field No 70: Soncho palustris-Archangelicetum litoralis 4O, Rubetum idaei Malinowski et Dziubałtowski 1914 em. Oberd. 1973 2O, Spergulario salinae-Puccinellietum distantis Feekes (1934) 1943 2/, Alnus glutinosa tree rows 2/, Juncetum gerardii 1/, Phalaridetum arundinaceae + /.

$\mathrm{X}$. Complex of meadows, pastures and heathlands was present in the lower parts of slightly inclined slopes and in vast depressions between glacially polished rock outcrops, in the central and southern parts of Seili. The area covered by this complex was decreasing, since meadows have not been mown for several decades, and it was partially afforested with deciduous and coniferous trees, mostly of foreign provenience. The composition of vegetation types is illustrated with two examples:

(12) Field No 19a: Alopecurus pratensis comm. 4O, Carum carvi-Alchemilla gracilis comm. 10, Parmelietalia saxatilis comm. 10, Trifolio medii-Agrimonietum 10/, Achillea ptarmica-Deschampsia caespitosa comm. +O, Poo irrigataePlantaginetum +/, Matricario matricarioidis-Polygonetum arenastri +/, Ribes alpinum-Sorbus aucuparia comm. +.;

(13) Field No 50: Alopecurus pratensis comm. 3O, Alopecurus pratensis comm. with Betula sp. and Populus sp. 3O, Potentilletum anserinae 1/, Lysimachio vulgaris-Filipenduletum 1/, Achillea ptarmica-Deschampsia caespitosa comm. +., Rubetum idaei.+ .
XI. Complex of nitrophilous forest edge communities occurred mainly in the central part of Seili in the vicinity of deciduous forests and plantations of trees on abandoned fields and meadows. It tended to increase its surface in course of secondary succession. Exemplary relevé shows its composition:

(14) Field No 71: Anthriscetum sylvestris Hadač 1978 3O/, Rubo-Epilobietum angustifolii Hadač in Hadač et al. 1969 2O, Lysimachio vulgaris-Filipenduletum 2O, Alopecurus pratensis comm. with Populus tremula 2O, Lysimachio vulgaris-Alnetum glutinosae 1/, Trifolio medii-Agrimonietum 1/, Rubetum idaei 1., Calamagrostietum epigeji +/, EpilobioGeranietum robertiani Lohm. in Oberd. et al. 1967 ex Görs et Th. Müller 1969 +/, Prunello-Plantaginetum Faliński (1961) $1963+/$.

XII. Complex of ruderal communities was stated in the central part of Seili around groups of buildings. It was composed mainly of frequently mown lawns, nitrophilous tall herb communities from Arction lappae and trodden communities of roads and paths.

(15) Field No 22a: Carum carvi-Alchemilla gracilis comm. 30, Cuscuto europaeae-Urticetum dioicae Balcerk. et Brzeg. 1999 nom. inval. 2O, Alopecurus pratensis comm. 2O, Rumici longifolii-Urticetum dioicae Balcerk. et Brzeg. 1999 nom. inval. 1O, Matricario matricarioidis-Polygonetum arenastri 1/, Poo irrigatae-Plantaginetum 1/, Geo urbani-Chelidonietum majoris Jarolímek et al. 1997+O, Veronico-Lamietum hybridi Kruseman et Vlieg. $1939+$ O, Rubetum idaei +., Parmelietalia saxatilis comm. +., Bryo argentei-Saginetum procumbentis Diem. et al 1940 nom. invers. r.

XIII. Complex of segetal communities was found only on Seili, in the vicinity of settlements, in small gardens and orchards. Its surface has diminished, as compared to the time when there was hospital on Seili. This complex was heterogenous and comprised, besides Veronico-Lamietum hybridi, connected with cultivated fields, also communities from other complexes.

(16) Field No 8a: Veronico-Lamietum hybridi 30, Carum carvi-Alchemilla gracilis comm. 2O, Alopecurus pratensis comm. 2O, Poo irrigatae-Plantaginetum 2/, Matricario matricarioidis-Polygonetum arenastri + /, Parmelietalia saxatilis comm. r..

XIV. Complex of water vegetation has not been delimited on the map. It occurred commonly in the coastal waters with slightly inclined bottom around all islands and skerries, and has been followed down to the depth of $2 \mathrm{~m}$. Dominant were communities of hydrophytes as in an exemplary relevé:

(17) Field No 72: Ranunculetum baudotii Br.-Bl. 1952 4O, Potametum perfoliati W. Koch 1926 em. Pass. 1964 2O, Phragmitetum communis 1O, Potametum filiformis W. Koch 1926 1., Cladophora sp. comm. +/, Zannichelietum palustris Lang $1967+$..

\section{Conclusions}

Presented above 14 types of vegetation complexes composd vegetation landscape typical for inner Finnish 
archipelago. This landscape, however, was changing in the study area as a result of diminishing human impact, and its least stable elements were complexes developed under traditional ways of land use. The complexes composed of natural communities, except for deciduous forests, were more stable, especially epilithic and of oligotrophic coniferous forests, as well as those connected with littoral. The map can be of benefit in the assessment of future landscape transformations and in other geobotanical studies, e.g. interpretation of distribution of the elements of flora.

Acknowledgements: The studies on Seili were possible due to the financial support of the Archipelago Research Institute of the University of Turku and from the Polish Committee of Scientific Research (Grant 6 P04C 022 10).

\section{References}

Анті T., Нӥмет-Анті L. \& JALAS J. 1968. Vegetation zones and their sections in northern Europe. Ann. Bot. Fennici 5(3): 169-211.

Balcerkiewicz S. \& Brzeg A. 2001. Potentillo argenteaeViscarietum vulgaris ass. nova - zespół pięciornika srebrnego i smółki pospolitej. In: E. Roo-ZIELIŃSKA \& J. Solon (eds.). Typologia zbiorowisk i kartografia roślinności w Polsce - rozważania nad stanem współczesnym, pp. 53-63. Prace Geograficzne 178, Warszawa.

Balcerkiewicz S., Brzeg A. \& Pawlak G. 1996. Próba geobotaniczno-krajobrazowej charakterystyki obszarów użytkowanych rolniczo przy zastosowaniu koncepcji sigmasocjacji. Zesz. Nauk. WSP Bydgoszcz 12: 17-43.

BalCerkiewicz S. \& WoJterska M. 1978. Sigmassoziationen in der hohen Tatra. In: R. TÜXEN (ed.). Assoziationskomplexe (Sigmeten), pp. 161-177. Ber. Internat. Sympos. der IVV Rinteln 1977, J. Cramer, Vaduz.

BALCERKIEWICZ S. \& WoJTERSKA M. 1998 (mscr.). Kompleksy zbiorowisk roślinnych. In: M. WOJTERSKA (ed.). Flora and vegetation of the island Seili in SW Finland. Raport ze studiów finansowanych przez Komitet Badań Naukowych, Projekt 6 P04C 022 10. Department of Plant Ecology and Environmental Protection, Adam Mickiewicz University, Poznań.

Dierssen K. \& Dierssen, B. 1996.Vegetation Nordeuropas. 838 pp. E. Ulmer Verlag, Stuttgart

Ericson L. \& Wallentinius H.-G. 1979. Sea-shore vegetation around the Gulf of Bothnia. Wahlenbergia 5: 1-149.

Hämet-Ahti L., Suominen J., Ulvinen T. \& Uotila P. (eds.). 1998. Retkeilykasvio. (Field Flora of Finnland), Ed. 4. 656 pp. Finnish Museum of Natural History, Botanical Museum, Helsinki.

HüBschman A. v. 1975. Moosgeselschaften des Nordwestdeutschen Tieflandes zwischen Ems und Weser. II Teil: Erdmoos-Gesellschaften. Herzogia 3:275-326.

Kasprowicz M. \& Wojterska M. 2004. The coniferous forests communities of the Seili Island in SW Finland. In: A. Brzeg \& M. Wotterska (eds.). Coniferous forests vegetation - differentiation, dynamics and transformations, pp. 23-34. Wydawnictwo Naukowe Uniwersytetu im. A. Mickiewicza w Poznaniu, Seria Biologia 69, Poznań.
KLEMENT O. 1955. Prodromus der mitteleuropäischen Flechtengesellschaften. 194 pp. Feddes Repertorium Beihefte 135 , Berlin.

MAAPERÄKARTTA 1: 20 000. 1997. 104304 Aaslaluoto. Geologian tutkimuskeskus. Maanmittauslaitos.

Medwecka-Kornaś A. 1983. Complexes of Plant Associations in the Polish Western Carpathian Mts. An Attempt towards symphytosociological Analysis of Vegetation Maps. Tuexenia 3: 217-226. Hannover.

РетёJä A. \& Juusti T. 1979. Archipelago Research Institute. $14 \mathrm{pp}$. University of Turku, Turku.

RATYŃSKA H. 2003. Plant cover as a result of anthropogenic changes in landscape exemplified by the River Główna catchment area (the middle Wielkopolska Province, Poland) 392 pp. Wydawnictwo Akademii Bydgoskiej im. Kazimierza Wielkiego, Bydgoszcz (in Polish).

Ratý́ska H., Wojterska M., Brzeg A. \& Kołacz M. 2010. Multimedialna encyklopedia zbiorowisk roślinnych Polski ver. 1.1. Instytut Edukacyjnych Technologii Informatycznych. Uniwersytet Kazimierza Wielkiego, Bydgoszcz.

Rivas-Martinez S. 1976. Sinfitosociologia una nueva metodologia para el estudio del paisaje vegetal. Anales del Instituto Botánico A. J. Cavanilles 33: 179-188.

Schwabe A. 1987. Fluß- und bachbegleitende Pflanzengesellschaften und Vegetationskomplexe im Schwarzwald. Diss. Bot. 102. 368 pp. J. Cramer. Berlin, Stuttgart.

Sıörs H. 1965. Forest regions. Acta Phytogeogr. Suec. 50:48-63.

ThanNHeISER D. 1982. Synsoziologische Studien am Meerestrand in Nord-Fennoskandien. In: K. Baadsvik \& O. I. Rønning (eds.). Fagmøte i vegetasjonsøkologi på Kongsvoll 14-16.03.1982. K. norske Vidensk. Selsk. Rapp. Bot. Ser. 1982-8: 36-47. Trondheim

TheurILLAT J. P. 1992. Etude et cartographie du paysage végétal (symphytocoenologie) dans la région d'Aletsch (Valais, Suisse). Mat. Levé géobot. Suisse 68. 381 pp. Lausanne, Geneve.

TuHKANEN S. 1980. Climatic parameters and indices in plant geography. Acta Phytogeogr. Suec. 67: 1-100.

TüXEN R. 1973. Vorschlag zur Aufnahme von Gesellschaftskomplexen in natürlichen potentiellen Vegetationsgebieten. Acta Botanica Academiae Scientiarum Hungaricae 19: 379-384. 
TüXEN R. 1977. Zur Homogenität von $\Sigma$-assoziationen ihrer syntaxonomischen Ordnung und ihrer Verwendung in der Vegetationskartierung. Documents Phytosociologiques N.S. 1: 321-327.

TüXEN R. 1978. Bemerkungen zur historischen, begrifflichen und methodischen Grundlagen der Synsoziologie. Ber. Internat. Sympos. der IVV Rinteln 1977. Sigmeten (Assoziationskomplexe) und ihre praktische Anwendung. 3-11. J. Cramer Vaduz.

TüXEN R. 1979. Sigmeten und Geosigmeten, ihre Ordnung und ihre Bedeutung für Wissenschaft, Naturschutz und Plannung. Biogeographica 16: 79-92.

TuHKanEN S. 1980. Climatic parameters and indices in plant geography. Acta Phytogeogr. Suec. 67:1-100.

Wirth V. 1972. Die Silikatflechten-Gemeinschaften in ausseralpinen Zentraleuropa. 305 pp. + phot. + tab. Dissertationes Botanicae 17. J. Cramer, Lehre.

WoJTERSKA M. 1998 (mscr.). Survey of vegetation types. In: M. WOJTERSKA (ed.). Flora and vegetation of the island
Seili in SW Finland. Raport ze studiów finansowanych przez Komitet Badań Naukowych, Projekt 6 P04C 022 10. Department of Plant Ecology and Environmental Protection, Adam Mickiewicz University, Poznań.

Wojterska M. 2003. Structure of vegetation landscapes. Case study - Międzychód-Sieraków Lakeland. 415 pp. Bogucki Wyd. Nauk., Poznań (in Polish).

Wojterski T. \& Wojterska H. 1993. Mapa roślinności rzeczywistej wyspy Seili w południowozachodniej Finlandii (Map of real vegetation of the island Seili in southwestern Finnland). Wiad. Bot. 37(3/4): $39-41$.

Wojterski T., Wojterska M. \& Wojterska H. 1998. Plant communities of the island Seili in the Archipelago of Turku (Finland). State in 1986. 1: 4 000. Department of Plant Ecology and Environmental Protection, Adam Mickiewicz University Poznań (Poland). 